DE

DE GRUYTER

OPEN

G
Journal of Intercultural Management

Vol. 7, No. 2, June 2015, pp. 31-47

DOI 10.1515/joim-2015-0009

Barbara Kożuch ${ }^{8}$

Jagiellonian University, Kraków

Katarzyna Sienkiewicz-Małyjurek ${ }^{9}$

Silesian University of Technology, Zabrze

Lidia Luty ${ }^{10}$

University of Agriculture in Krakow, Kraków

\title{
Rational and Relational Bases of Public Managers' New Profiles in the Context of Trust Research
}

Abstract: Competencies are a set of distinctive resources and opportunities. They relate to specific capabilities of management and to performance of management methods. In the catalogue of existing managerial competencies, an increasingly important role is played by trust. The deep insight in this field of literature gives grounds for the inference that trust is rather a means to achieve public organisations' goals, than being the end in itself. Therefore in this article we have assumed, that contemporary competencies, to a large degree, rely on trust which is rationally and relationally rooted.

The main aim of this paper is to identify and evaluate components of trust with reference to the competences of public managers mirrored in their new profiles. To achieve the goal of the article, publications of the field of organisational studies and public management which aim to show the importance of creating trust within an organisation were reviewed to identify main managerial competences analysed in the context of public trust as an

\footnotetext{
${ }^{8}$ barbara.kozuch@uj.edu.pl

${ }^{9}$ Katarzyna.Sienkiewicz-Malyjurek@polsl.pl

${ }^{10}$ rrdutka@cyf-kr.edu.pl
} 
important factor of improving public organisations. Moreover, the results of a survey with 93 respondents carried out in 2014 in 8 units of local public administration from the Malopolska Region were used. As a result the main components of trust in new public managers' profiles have been identified and assessed.

Key words: competencies of public managers, new profiles of public managers, rational and relational based public trust, public management

\section{INTRODUCTION}

Functioning within an organisation as well as beyond it, rests on collaboration and interdependence, and members of specific organisations rely on each other in order to attain their organisational and personal goals. Therefore, tremendous importance is attached to trust that encourages behaviours helping to handle risk and uncertainty related to collaboration [Mayer et al. 1995; Jones and George 1998]. The trust level within organisations is however positively correlated with efficiency and performance. Moreover, trust is regarded as both glue and lubricant of social capital [Anderson and Jack 2002; Welter 2012; Åm 2011]. Thus, it is necessary for managers [Porumbescu et al. 2013; Möllering et al. 2004] to appreciate the features and role of trust and to undertake activities that generate a conviction among their employees that their competences allow them to carry out their obligations [Lee 2004; Cook and Wall 1980]. This refers to managers in the private sector as well as in the public and non-governmental sectors.

However, public trust is hardly a novelty and "our instrumental knowledge about building, maintaining, or recovering public trust is quite limited" [Thomas 1998, p. 168]. Furthermore, little empirical research has concerned the influence exerted by trust on managers' work in organisations [Tzafrir 2006, p. 1601]. On top of that, due to differences in goals and operations between the public and private sectors, there are no possibilities of transferring experience and theory set up on the basis of activities performed by specific organisations between sectors [Thomas 1998, p. 188]. Therefore, there is a need to identify and assess the components of trust with reference to the competences enjoyed by public managers, which constitutes the objective of this paper. This paper assumes that contemporary public managers base their management on trust. In the course of analyses conducted, the competences possessed by public managers and foundations of trust have been revealed. In addition, rational and relational aspects in public organisations were pinpointed, and the relationship between trust and public managers' competences was characterised. 


\section{THEORETICAL BACKGROUND}

\section{Managerial competences in public sector}

Competences constitute the set of distinctive resources and capacities connected to the structure of the specific organisation, technologies used and inter-organisational relationships. Basically, they include managers' competences that cover management staff's capacities and knowledge, including their capacity to solve problems, manage changes, innovations and resources, leadership and continuous organisational improvement [Abraham 2001; Kożuch and SienkiewiczMałyjurek 2013]. According to the theory established by H. Mintzberg [2005], the role of managers boils down to maintaining contacts with other persons, gathering, processing, transferring and storing information, and it also refers to decisionmaking. Managers are significant for the operations conducted by both enterprises as well as public institutions.

In the public sector a basic task assigned to managers is to ensure effective provision of high-quality public services to the society. They address social problems given the theories on economic rationality [Kożuch 2010, pp. 347-351]. Traditionally, key competences enjoyed by public managers encompass the following skills: technical-organizational (basic professional skills), programme (capability to activate processes) and collaboration [Lane and Wolf 1990]. These competences are based on the knowledge used in the managerial work, experience, professionalism, and a predisposition to attain goals focused on the accomplishment of the public interest [Kożuch and Sienkiewicz-Małyjurek 2014]. They are essential because specific responses, professionalism and flexibility are expected from managers under any circumstances. Their role is to create a vision, convey it to the organisation's members and motivate them to accomplish that vision.

Presently public managers have to adjust to shifts in organisational and environmental requirements, manage numerous relationships as well as handle stress and uncertainty [Dragoni 2009, p. 731]. These activities require transparent organisational regulations as well as responsible and involved employees. Accordingly, central to organisational relationships is a high trust level which allows managers to delegate tasks to employees, and belief in the purpose of tasks delegated and their fulfilment in a diligent and eager manner. Literature studies provided in the further section of the paper show that trust proves to be an essential value in the work of contemporary public managers. Therefore, it is justified to incorporate them into basic categories in the studies of public sector managerial effectiveness.

\section{The basis of trust}

Trust "is at the core of all relationships" [Mishra and Morrissey 2000, p. 14]. It has long enjoyed the interest among researchers from many scientific disciplines, 
including sociology, economics, management sciences and psychology [Rousseau et al. 1998; Lewicki et al. 1998; Korczynski 2000]. This results from its positive impact on the operations carried out by organisations and the progress of processes executed. Judy Pate et al. [2007, p. 459] stated that trust affects organisational efficiency and effectiveness, a positive psychological contract, lower employee turnover, individual performance, organisational flexibility and performance, and successful change management. Similar views are held by A.R. Elangovan et al. [2007, p. 4] when writing that trust reinforces team work, creativity, and it provides the foundations for inter-organisational collaboration. It encourages building lasting relationships and enhances problem solving, thereby constituting significant social capital [Fukuyama 1995; Carnevale 1995]. Meanwhile F. Xavier Molina-Morales et al. [2011, p. 119] argues that trust diminishes transactional and agency costs, influences effectiveness and performance of market exchanges, and it facilitates adaptation to changes and complex circumstances. Trust is also a factor which affects knowledge sharing and use, and stimulates innovations [Holste and Fields 2010; Dovey 2009]. Moreover, it may act as a substitute of formal control and help to handle conflicts [Wicks 1999; Jones G.R. and George 1998, pp. 531-532]. However, scarcity or a low level of trust may lead to organisational dysfunctions such as reduced motivation among employees or a decline in involvement in tasks performed [Gould-Williams 2003, p. 31]. For these reasons, trust appears to be significant factor in managers' work.

Trust is such a complex and multifaceted issue, and none of the existing definitions are able to encompass it and convey its essence. Though, compilation of few popular definitions used in the literature may advance its understanding, namely:

- Trust is "the willingness of a party to be vulnerable to the actions of another party based on the expectation that the other will perform a particular action important to the trustor, irrespective of the ability to monitor or control that other party" [Mayer 1995, p. 712].

- "Trust is a psychological state comprising the intention to accept vulnerability based upon positive expectations of the intentions or behaviour of another" [Rousseau et al. 1998, p. 395].

- Trust is a "confident positive expectations regarding anther's conduct" [Lewicki et al. 1998, p. 439].

- Trust is "an expression of confidence between the parties in an exchange of some kind-confidence that they will not be harmed or put at risk by the actions of the other party or confidence that no party to the exchange will exploit the other's vulnerability" [Jones and George 1998, pp. 531-532].

- Trust is the expectation that „other people, or groups or institutions with whom we come into contact - interact, cooperate - will act in ways conducive to our 
well-being. Because in most cases we cannot be sure of that, as others are free agents, trust is a sort of gamble involving some risk. It is a bet on the future, contingent actions of others" [Sztompka 1999, pp. 25-26].

- "Interpersonal trust is the trust placed by the individual boundary spanner in her individual opposite member. The term inter-organizational trust is defined as the extent of trust placed in the partner organization by the members of a focal organization" [Zaheer 1998, p. 142].

The reference literature contains much more definitions of trust, but based on those cited in this paper it is possible to characterise its distinctive features. Principally, trust is positive in its character, it is focused on actions and accompanies collaboration on the micro, mezzo and macro scale. It relies on the behaviours displayed by a trustee and occurs in the circumstances of vulnerability, uncertainty and risk. Additionally, trust is concerned with expectations and predictability of trustee's behaviours by a trustor, its willingness and commitment in action. It rises or declines in time, depending on the level of existing relationships. Moreover, it refers not only to convictions but also to decisions and activities [Dietz and Den Hartog 2006, p. 558]. As a fragile resource it requires openness, commitment, honesty, care and refrainment from self-serving behaviour [Dovey 2009, p. 314]. According to the opinion voiced by Denise M. Rousseau, trust ranges "from a calculated weighing of perceived gains and losses to an emotional response based on interpersonal attachment and identification" [Rousseau et al. 1998, p. 398]. In essence, it refers to the functioning of private organisations as well as public and non-governmental ones. They may analysed in terms of existing types (e.g. basic, simple, blind, or authentic) [Starnes et al. 2005, p. 3], forms (e.g. deterrence-based, calculus-based, relational, and institution-based trust) [Rousseau et al. 1998, pp. 398-401] and levels (e.g. interpersonal, organisational, intra-organisational, interorganisational trust) [Ganesan and Hess 1997]. While the scope and level of trust rely on multiple factors, among which the following may be enumerated: level of organisational advance, existing interpersonal and inter-organisational relations, experience, type of leadership, etc. Thus, it represents a broad and rich research spectrum.

\section{Rational and relational trust in public organisations}

Activities conducted by public organisations involve exerting influence on other organisations and citizens in order to fulfil public interest. To make these activities effective, a high trust level is crucial. Public trust can be defined as "citizens" knowledge and belief in public officials and public institutions that they are able to provide policies and programmes that benefit them and protect their rights" [Kożuch and Dobrowolski 2014, p. 49]. It results from relationships between public organisations with external stakeholders as well as their employees. After all, it is 
assumed that it is unlikely to build external trust without internal trust.

Public trust rests on organisational publicness and public accountability. From the overall perspective publicness is defined as "characteristics of an organisation which reflects the extent the organisation is influenced by political authority" [Bozeman and Bretschneider 1994, p. 197]. From the organisational perspective, publicness embraces relations with the surrounding setting, objectives, structure and values. It applies to organisations across all sectors as operations conducted by each organisation is, to a certain extent, based on transparency, e.g. with regard to relations with the surrounding setting. Regarding public organisations, though, this transparency is more robustly exposed and its importance is far bigger. Clearly, this shows that public organisations disclose what public services they provide, to what extent they implement a planned budget and how they spend public resources, what investments they make or what operations they plan to launch in the future. According to M. Shamsul Haque, publicness in the public sector "has usually been understood in terms of its distinguishing features, including its service norms such as impartiality and openness, its principles such as equality and representation, its monopolistic and complex nature, and its longer and broader social impacts" [Haque 2001, p. 66].

Whereas public accountability in the broader context is perceived from the viewpoint of principles, attitudes and organisational behaviours, and emphasizes such values as: transparency, responsibility, fairness, democracy, efficiency, responsiveness, honesty [Mulgan 2002]. While in a narrow sense, it relates relationships between public organisations and their stakeholders which specify the duties to clarify and justify activities undertaken by these organisations, and they give citizens the right to ask questions, express their views and set requirements [Romzek and Dubnick 2001, Romzek et al. 2012]. Therefore, public accountability is connected with the citizens' expectations of the state and public administration, especially with regard to: "solving problems identified and articulated by citizens on their behalf and in their interest; preventing conflicts due to balancing values shared by the society; providing attention to a high standard of public services on the basis of social justice; economically effective and calculable functioning of administration [...]" [Kożuch and Dobrowolski 2014, p. 38]. Therefore, it may be ascertained that public trust refers to inter-organisational and intra-organisational level. Inter-organisational trust suggests the trust level of the partner organisation relative to the focal organisation based on such factors as: reliability, predictability, and fairness [Zaheer et al. 1998]. Nevertheless, this article places an emphasis on the intra-organisational level, because it is impossible to produce trust between organisations and local communities without this type of trust.

Intra-organisational trust pertains to horizontal and vertical relationships occurring within a single organisation [Mayer et al. 1995; Gilbert et al. 1998, Li et 
al. 2012]. Graham Dietz and Deanne N. Den Hartog [2006, p. 570] identified six different work-based relationships including: relationships between an employee and supervisor, between two employees, between an employee and employer, between an employee and whole organisation, between organisational departments and multiple relationships within the organisation. Level of intra-organisational trust depend thus not only on interpersonal relationships but also employees' perception of operational practices formally used [Vanhala and Ahteela 2011]. They may be classified into the following continuum of degrees of intra-organisational trust [Dietz and Den Hartog 2006, p. 563]:

- deterrence-based: distrust;

- calculus-based: low trust;

- knowledge-based: confident trust;

- relational-based: strong trust;

- identification-based: complete trust.

Critical analysis of the existing literature allow definition of intra-organisational public trust as an individual, group or collective justification when establishing and developing trust relationships rationally (i.e. common goals, routines, procedures, staff competences, etc.) or relationally rooted (i.e. shared goals, norms and values, codes of conduct) considered in the context of meeting public needs [Blind 2006; Keele 2007; Thomas 1998]. Hence, it may considered as sufficient to separate two types of intra-organisational public trust, i.e. rational and relational trust.

Rational-based trust originates from individual assessments of existing relations, competences possessed by employees and supervisors as well as current staff attitudes. Also, it applies to practical experience and logical deliberations with regard to activities jointly executed. Thus, it has a normative aspect [Pedersen et al. 2014] and entails a cognitive attitude [Frost-Arnold 2014]. Meanwhile, from the perspective of the relational approach, trust is principally generated through direct interactions resulting from voluntary collaboration and commitment by all parties. In the context of these relationships, common conduct standards are defined, communication practices are formulated, or subsequent joint ventures are recognised. Relational-based trust is connected with primary interdependencies, frequently emotional ones for both parties, stems from convictions and good will [Faulkner 2007]. It changes in time - it is initiated, built, bolstered, or even destroyed as a result of current transactions [Tabak and Smith 2005, p. 178].

Due to the opportunities of gathering experience, identifying expectations, creating shared values or minimising opportunistic risks, the studies described in the reference literature underline the advantage of relational-based trust over rational-based trust [Poppo et al. 2015]. Though both types enumerated have different meaning for the decision-making process. Rational trust suggests benefits from collaboration based on the continuous calculation, whereas relational trust 
is grounded in irrational experience and repetitiveness of interactions. For that reason, both identified types of intra-organisational public trust are critical to the work performed by public managers.

\section{Trust versus competences of new public managers}

The literature on the subject increasingly stresses the significance of trust in managers' work. Specifically, this arises from the need to continually align capabilities for actions to ongoing circumstances, to solve conflicts, manage knowledge, coordinates operations, etc. [McAllister 1995]. Research conducted by B. Kożuch reveals that a suitable set of managers' competencies is at the heart of building and restoring organisational trust [Kożuch and Dobrowolski 2014, p. 28]. Competences of public managers encompass experience, and capacity to accomplish organisational goals as well as consider social sensitivity [Farnham and Horton 1996, p. 7]. Hence, these managers tend to be creators of public trust analysed from the organisational perspective. They may generate public trust through their management style that ensures appropriate organisation of these institutions so as to fulfil citizens' needs in compliance with the mission pursed by the organisations. They discharge their obligations by consistent authorisation of actions and implementation of accountability mechanisms. Their objective is to develop public services offered, thereby meeting social needs in the long-term. This results from the necessity of carrying out long-term ventures and interactions to build public trust. Occasional and sporadic activities contribute to enhancing social satisfaction, yet they fail to strengthen public trust [Wang and Van Wart 2007, p. 270]. To this end, public managers also need reliable employees. Managers' trust towards employees has huge impact on the course of decision-making processes [Tzafrir 2006, p. 1602]. Meanwhile, mutual trust is heavily dependent on that how they perceive their employees, which is further manifested in the manner they are treated [Shore et. al. 1995]. Broadly speaking, managers initiate creation of trust among their employees through trustworthy behaviour. Factors that influence employees' perceptions of managerial trustworthiness contain [Whitener et al. 1998, p. 516]:

- behavioural consistency,

- behavioural integrity,

- sharing and delegation of control

- communication (e.g. accuracy, explanations, and openness),

- demonstration of concern.

Whilst trustworthy behaviour of managers is affected by organisational factors (e.g. HR policies and procedures), relational (e.g. expectations) and individual (e.g. values) [Whitener et al. 1998, p. 519]. The factors specified show that trustworthy behaviour is central to build and maintain trust. This is closely linked to such competences used by public managers as programme capability and collaboration. 
They require both actions, stemming from analytical discussions as well as relational capabilities. Therefore it may be assumed that competences of contemporary public managers are closely connected with rational and relational dimensions of trust.

\section{METHODOLOGY}

Presented work is a theory-based empirical study. Identification of intraorganisational trust was accomplished based on questionnaire surveys in 8 commune offices in the Małopolskie Province. The research was pilot in its nature.

The survey questionnaire was conducted on the organisational concept for public trust perspective [Kożuch and Dobrowolski 2014, pp. 11-109, 219-229]. Having in mind this concept, questionnaires devised by R.B. Shaw targeted to business organisations were adapted [Shaw 1997].

It was assumed that survey would cover 100 randomly selected employees from these offices. Such sample selection implies that statistical inference based on the findings obtained from the sample may only refer to the community surveyed. The analysis of the results selected is based on 93 properly completed questionnaires.

\section{RESULTS}

\section{Identification of components of rational and relational trust}

Based on research conducted, fundamental components producing rational and relational trust were identified. Essentially, public managers' competences related to knowledge, capabilities and operational practice were assigned to rational trust. Whereas relational trust covered interactions, mutual attitudes and interdependencies between public managers and their employees. The classification was displayed in Table 1.

Table 1. Components of rational and relational trust

\begin{tabular}{l|l} 
& Component \\
\hline Rational trust & Relational trust \\
\hline Reliability & Managers' openness \\
Fulfilment of obligations & Concern of public affairs \\
Effectiveness & Mutual friendliness \\
Attitude to changes & Appreciation of employees competencies \\
Clarity of goals & Compliance principles, values and practice \\
Trust to managers & Commitment \\
Openness on matters of citizens & Attitude to employees \\
Cooperation & Bonds with co-workers \\
Delegation of powers & Impartiality \\
Work as the basis for assessments & Positive relationships with immediate supervisors \\
Fairness & Feeling free to express view \\
Consistency of organisational practices & Propensity to trust
\end{tabular}


Knowledge about office

Objectives and measures compliance

Empowerment

Participation

Source: own elaboration based on the study completed, 2014.

It should be also highlighted that in the case of some components a boundary between rational and relational trust is not clear. For example, this applies to compliance with the principles and practice of organizational values. This may come not only from rational but also emotional motives. The classification adopted is premised on the prevalent aspect - rational or relational.

\section{Assessment of the level of rational and relational trust}

Creation of trust rests on fulfilment of requirements related to its particular components. This is made possible due to adequate managerial competences. Respondents were asked to assess the extent to which given factors characterizing a person decide that they would be able to trust that person in the performance of their duties. The analysis of ratings was carried out from the perspective of identified components of rational and relational trust, thereby describing a high, medium and low level. The results obtained were provided in Table 2.

Table 2. Assessment of components of rational and relational trust [\%]

\begin{tabular}{|l|c|c|c|}
\hline \multirow{2}{*}{ Specification } & \multicolumn{3}{c|}{ Level } \\
\cline { 2 - 4 } & high & medium & low \\
\hline \multicolumn{2}{|c|}{ Components of rational trust } \\
\hline Reliability & 79,6 & 19,3 & 1,1 \\
\hline Fulfilment of obligations & 74,2 & 14,0 & 11,8 \\
\hline Effectiveness & 66,6 & 28,0 & 5,4 \\
\hline Attitude to changes & 65,6 & 22,6 & 11,8 \\
\hline Clarity of goals & 63,4 & 24,8 & 11,8 \\
\hline Trust in managers & 63,4 & 22,6 & 14,0 \\
\hline Openness on matters of citizens & 58,0 & 26,9 & 15,1 \\
\hline Cooperation & 49,5 & 24,7 & 25,8 \\
\hline Delegation of powers & 47,3 & 38,7 & 14,0 \\
\hline Work as the basis for assessments & 46,2 & 30,1 & 23,7 \\
\hline Fairness & 45,2 & 32,3 & 22,5 \\
\hline Consistency of organisational & \multicolumn{3}{|c|}{} \\
practices & 39,8 & 25,8 & 34,4 \\
\hline Knowledge about office & 32,3 & 32,3 & 35,4 \\
\hline Objectives and measures compliance & 32,3 & 51,6 & 16,1 \\
\hline Empowerment & 29,0 & 44,1 & 26,9 \\
\hline Participation & 24,7 & 43,0 & 32,3 \\
\hline & 76,4 & 7,5 \\
\hline Managers' openness & 16,1 & \\
\hline
\end{tabular}




\begin{tabular}{|l|l|l|l|}
\hline Concern of public affairs & 76,1 & 17,4 & 6,5 \\
\hline Mutual friendliness & 67,7 & 19,4 & 12,9 \\
\hline $\begin{array}{l}\text { Appreciation of employees } \\
\text { competencies }\end{array}$ & 67,7 & 18,3 & 14,0 \\
\hline $\begin{array}{l}\text { Compliance principles, values and } \\
\text { practice }\end{array}$ & 66,7 & 22,5 & 10,8 \\
\hline Commitment & 57,0 & 29,0 & 14,0 \\
\hline Attitude to employees & 55,9 & 24,7 & 19,4 \\
\hline Bonds with co-workers & 55,9 & 26,9 & 17,2 \\
\hline Impartiality & 53,7 & 33,3 & 12,9 \\
\hline $\begin{array}{l}\text { Positive relationships with immediate } \\
\text { supervisors }\end{array}$ & 36,6 & 31,2 & 32,2 \\
\hline Feeling free to express view & 30,1 & 38,7 & 31,2 \\
\hline Propensity to trust & 23,7 & 33,3 & 43,0 \\
\hline
\end{tabular}

Source: own elaboration based on the study completed, 2014.

Among components that form rational trust the highest rating was given to reliability $(79,6 \%)$, fulfilment of obligations $(74,2 \%)$ and effectiveness $(66,6 \%)$. These components were also characterised by the highest diversity of responses. Thus, it may be claimed that they work as foundation for building rational trust. Whereas such components as participation, empowerment, objective and measures compliance and knowledge about the office scored lowest ratings. This implies individualisation of public managers' work. The findings were illustrated in Figure 1.

Figure 1. Assessment of components of rational trust [\%]

\section{Komponenty zaufania racjonalnego [\%]}

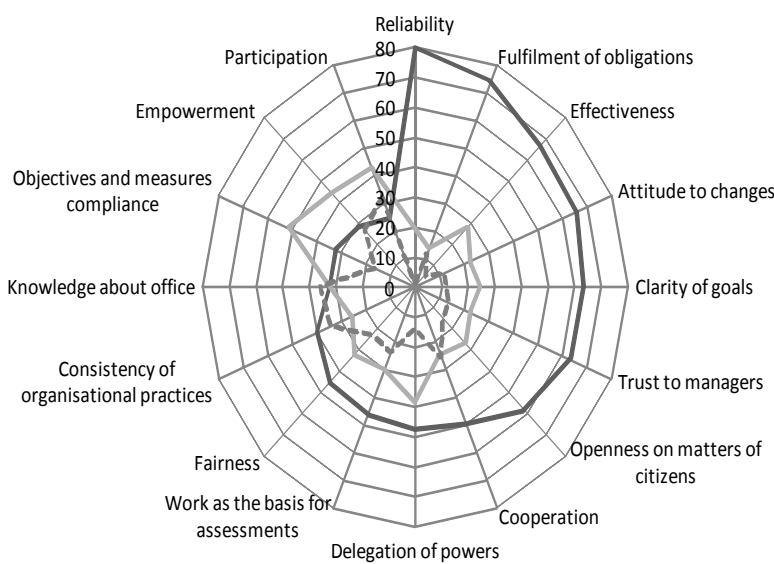

Source: own elaboration based on the study completed, 2014. 
Meanwhile, in the case of components of relational trust, manager's openness $(76,4 \%)$, concern of public affairs $(76,1 \%)$, mutual friendliness $(67,7 \%)$ and appreciation of employees' competences $(67,7 \%)$ topped the list. The lowest rating went to propensity to trust, feeling free to express view, positive relationships with immediate supervisors. Clearly, these results demonstrate appropriateness of relationships between public managers and employees as well as formality and superficiality of these relationships. Its potential upshot may be failure to exploit full potential of employees and low level of relational trust. The results attained were presented in Figure 2.

Figure 2. Assessment of components of relational trust [\%]

\section{Komponenty zaufania relacyjnego [\%]}

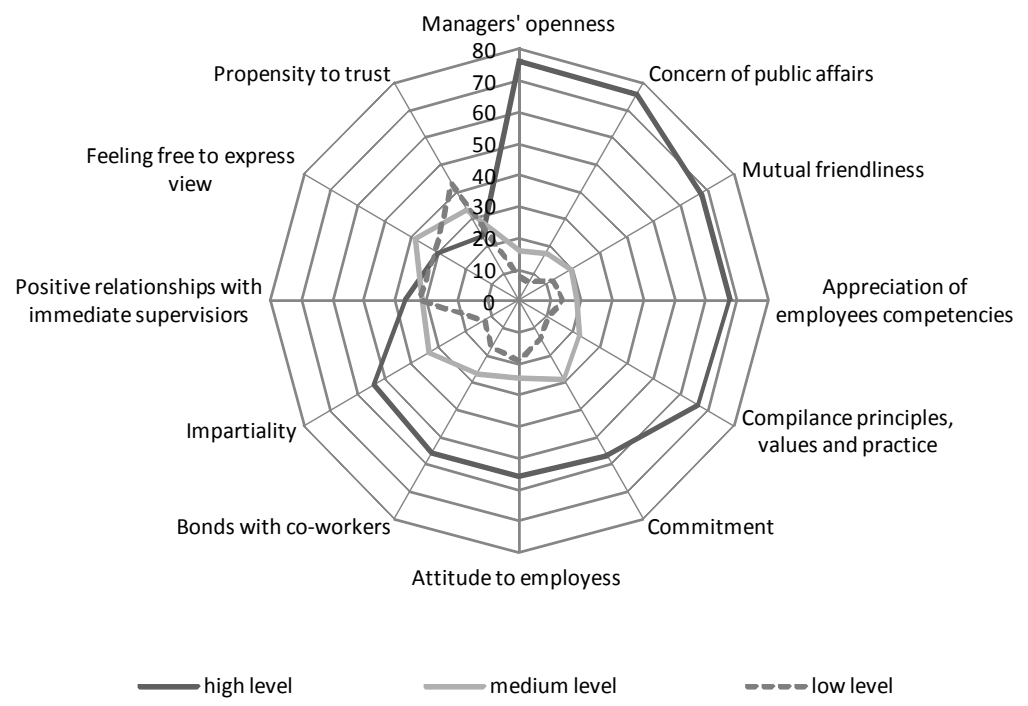

Source: own elaboration based on the study completed, 2014.

Results gained show how surprising opinions characterizing the nature of intra-organisational public trust are. Researched trust is based not only on rational judgements but also represents relation-based trust. Reliability, effectiveness, positive attitude to change, clarity of goals, belief in management and openness on citizens affairs are good examples of antecedents of rational trust while openness of managers, concern for public affairs, mutual friendliness, faith in the ability of employees, compliance of principles and values of the practices, and commitment are antecedents of relational trust. 


\section{CONCLUSIONS}

The subject of trust is a critical factor to effectively meeting public needs. It has been recognised that trust within organisations is of great importance. Despite significant theoretical work over the past several years, the phenomenon of intraorganisational public trust and its development remains elusive in theory and practice. We have argued that the pursuit of scientific clarity has made researchers confused and can make the concept of intra-organisational public trust more difficult to understand. It underlines the significance of intra-organisational public trust in daily organisational behaviours. It helps achieve greater effectiveness of activities and better results.

In the course of research completed it was claimed that:

1. Trust constitutes a means used to deliver goals of public organisations and manifests itself in managers' competences which include analytical activities as well as relational capabilities. Therefore, public managers' competences are closely connected with rational and relational dimensions of trust.

2. Rational trust arises based on rational assessment and evidence-based judgement. Among identified components of that type of trust, reliability, fulfilment of obligations and effectiveness received highest ratings, whereas participation, empowerment, objectives and measures compliance, and knowledge about the office ranked lowest.

3. Relational trust is grounded in the emotional and psychological aspects that form the relationship. In this aspect top ratings went to manager's openness, concern for public affairs, mutual friendliness and appreciation of employees' competences. Meanwhile, propensity to trust, feeling free to express views and positive relationships with immediate supervisors received lowest ratings.

4. The assessment of trust components in public managers' work reveals appropriateness and formality of their relationships with employees and individualisation of their work. Its outcome may be failure to exploit employees' full potential and lack of possibilities to build a high trust level. Respondents recognise the need for public managers to principally use traditional, technical and organisational and programme capabilities. It is necessary to bring bigger focus on capacities related to building and maintaining trust relationships with employees.

The research completed requires further in-depth studies due to ongoing limitations. These limitations include the territorial scope that exclusively covers the Małopolskie Province. On top of that, the research only covered selected employees from commune offices. Despite these limitations, the significance of trust for public managers' work was analysed, and fundamental components of rational and relational trust were identified and assessed. However, due to the growing role of trust for functioning of public organisations, including public managers' work, it 
is essential to continue launched research whose findings were illustrated in this paper. The planned future research should encompass larger territorial scope and deep insight trust-based organisational relationships.

\section{Bibliography}

Abraham S.E., Karns L.A., Shaw K.,Mena M.A. (2001), Managerial competencies and the managerial performance appraisal process, "Journal of Management Development", vol. 20, no. 10, pp. 842-852.

Åm H. (2011), Trust as Glue in Nanotechnology Governance Networks, "NanoEthics", vol. 5, no. 1, pp. 115-128.

Anderson A.R., Jack S.L. (2002), The articulation of social capital in entrepreneurial networks: a glue or a lubricant?, "Entrepreneurship \& Regional Development", vol. 14, no. 3, pp. 193-210.

Blind P.K. (2006), Building Trust in Government in the Twenty-first Century: Review of Literature and Emerging, Conference Proceedings, 7th Global Forum on Reinventing Government Building Trust in Government 26-29 June 2007, Vienna, Austria, pp. 3-8.

Bozeman B., Bretschneider S. (1994), The "Publicness Puz:le" in Organization Theory: A Test of Alternative Explanations of Differences between Public and Private Organizations, "Journal of Public Administration Research and Theory", vol. 4, no. 2, pp. 197-223.

Cameron W. (2004), Public accountability: Effectiveness, equity, ethics, "Australian Journal of Public Administration", vol. 63, no. 4, pp. 59-67.

Carnevale D.G. (1995), Trustworthy government: Leaderships and Management Strategies for Building Trust and High Performance, San Francisco: Jossey Bass.

Cook J., Wall T. (1980), New work, attitude measures of trust, organizational commitment and personal need non-fulfilment, "Journal of Occupational Psychology", vol. 53, pp. 39-52.

Dietz G., Den Hartog D.N. (2006), Measuring trust inside organisations, "Personnel Review", vol. 35 , no. 5 , pp. $557-588$.

Dovey K. (2009), The role of trust in innovation, "The Learning Organization", vol. 16, no. 4, pp. 311-325.

Dragoni L., Tesluk P.E., Russell J.E.A., Oh, I.-S. (2009), Understanding managerial development: Integrating developmental assignments, learning orientation, and access to developmental opportunities in predicting managerial competencies, "Academy of Management Journal", vol. 52, no. 4, pp. $731-743$.

Elangovan A.R., Auer-Rizzi W., Szabo E. (2007), Why don't I trust you now? An attributional approach to erosion of trust, "Journal of Managerial Psychology", vol. 22, no. 1, pp. 4-24.

Farnham D., Horton S. (1996), Public Managers and Private Managers: Towards a Professional Synthesis?, in Farnham D., Horton S., Barlow J., Hondeghem A. (ed.), New Public Managers in Europe, London: Macmillan Press Ltd.

Faulkner P. (2007), A genealogy of trust, "Episteme”, vol. 4, no. 3, pp. 305-321.

Frost-Arnold F. (2014), The cognitive attitude of rational trust, "Synthese: An International Journal for Epistemology, Methodology and Philosophy of Science", vol. 191, no. 9, pp. 1957-1974. 
Fukuyama F. (1995), Trust: The Social Virtue and the Creation of Prosperity, New York: Free Press.

Ganesan S., Hess R. (1997), Dimensions and Levels of Trust: Implications for Commitment to a Relationship, "Marketing Letters", vol. 8, no. 4, pp. 439-448.

Gilbert J., Li-Ping A., Tang, T. (1998), An examination of organizational trust antecedents' "Public Personnel Management", vol. 27, no. 3, pp. 321-332.

Gould-Williams J. (2003), The importance of HR practices and workplace trust in achieving superior performance: a study of public-sector organizations, "International Journal of Human Resource Management", vol. 14, no. 1, pp. 28-54.

Haque M.S. (2001), The Diminishing Publicness of Public Service under the Current Mode of Governance, "Public Administration Review", vol. 61, pp. 65-82.

Holste J.S., Fields D. (2010), Trust and tacit knowledge sharing and use, "Journal of Knowledge Management", vol. 14, no. 1, pp. 128-140.

Jones G.R., George J.M. (1998), The Experience and Evolution of Trust: Implications for Cooperation and Teamwork, "The Academy of Management Review", vol. 23, no. 3, pp. 531-546.

Keele L. (2007), Social Capital and the Dynamics of Trust in Government, "American Journal of Political Science", vol. 51, no. 2, pp. 241-254.

Korczynski M. (2000), The Political Economy of Trust, "Journal of Management Studies", vol. 37, no. 1, pp. 1-21.

Kożuch B., Dobrowolski Z. (2014), Creating Public Trust. An Organisational Perspective, Frankfurt am Main, Berlin, Bern, Bruxelles, New York, Oxford, Wien: Peter Lang GmbH, Internationaler Verlag der Wissenschaften.

Kożuch B., Sienkiewicz-Małyjurek K. (2014), New Requirements for Managers of Public Safety Systems, "Procedia - Social and Behavioral Sciences", vol. 149, pp. 472-478.

Kożuch B., Sienkiewicz-Małyjurek K. (2013), Kompetencje menedżerskie i crynniki sukcesu w zarzqdzaniu projektami, „Przedsiębiorczość i Zarządzanie”, vol. 14, no. 11(1), pp. 105-115.

Kożuch B. (2010), Kompetencje menedżerów organizacji publicznych: teoria a praktyka zarzqdzania, „Prace Naukowe Uniwersytetu Ekonomicznego we Wrocławiu”, vol. 156, pp. 347-351.

Lane L.M., Wolf J.F. (1990), The human resource crisis in the public sector, Westport: Quorum Books.

Lee H.-J. (2004), The role of competence-based trust and organizational identification in continuous improvement, "Journal of Managerial Psychology", vol. 19, no. 6, pp. 623-639.

Lewicki R.J., McAllister D.J., Bies R.J. (1998), Trust and distrust: New relationships and realities, "The Academy of Management Review", 23(3), 438-458.

Li P.P., Bai Y., Xi Y. (2012), The Contextual Antecedents of Organizational Trust: A Multidimensional Cross-level Analysis, "Management and Organization Review”, vol. 8, pp. 371-396.

Mayer R.C., Davis J.H., Schoorman F.D. (1995), An Integrative Model of Organizational Trust, "The Academy of Management Review", vol. 20, no. 3, pp. 709-734.

McAllister D.J. (1995), Affect- and Cognition-Based Trust as Foundations for Interpersonal Cooperation in Organizations, "Academy of Management Journal”, vol. 38, no. 1, pp. 24-60. 
Mintzberg H. (2005) Prøywódðtwo, Gliwice: Helion.

Mishra J., Morrissey M.A. (2000), Trust in Employee/Employer Relationships: A Survey of West Michigan Managers, "Seidman Business Review”, vol. 6, no. 1, pp. 14-15.

Molina-Morales F.X., Martínez-Fernández M.T., Torlò V.J. (2011), The Dark Side of Trust: The Benefits, Costs and Optimal Levels of Trust for Innovation Performance, "Long Range Planning", vol. 44, no. 2, pp. 118-133.

Möllering G., Bachmann R., Lee S.H. (2004), Introduction: Understanding Organizational TrustFoundations, Constellations, and Issues of Operationalisation, "Journal of Managerial Psychology", vol. 19, no. 6, pp. 556-570.

Mulgan R. (2002), Comparing Accountability in the Public and Private Sectors, "Australian Journal of Public Administration", vol. 59, no. 1, pp. 87-97.

Pate J., Beaumont P., Stewart S. (2007), Trust in senior management in the public sector, "Employee Relations", 29(5), pp. 458-468.

Pedersen N.J.L.L., Ahlström-Vij K., Kappel K. (2014), Rational trust, "Synthese: An International Journal for Epistemology, Methodology and Philosophy of Science”, vol. 191, no. 9, pp. 1953-1955.

Poppo L., Zhou K.Z., Li J.J. (2015), When can you trust "trust”? Calculative trust, relational trust, and supplier performance, "Strategic Management Journal”, doi: 10.1002/smj.2374.

Porumbescu G., Park J., Oomsels P. (2013), Building trust: communication and subordinate trust in public organizations, "Transylvanian Review of Administrative Sciences", vol. 38 E, pp. 158-179.

Romzek B., Dubnick M. (2001), Accountability in the Public Sector: Lessons from the Challenger Tragedy [in:] Stivers C. (ed.) Democracy, Bureaucracy, and Administration Boulder, Boulder: Westview Press, pp. 182-204.

Romzek B., LeRoux K., Blackmar J.M. (2012), A Preliminary Theory of Informal Accountability among Network Organizational Actors, "Public Administration Review", vol. 72, no. 3, pp. 442-453.

Rousseau R.M., Sitkin S.M., Burt R.S., Camerer C. (1998), Not so different after all: a crossdiscipline view of trust, "Academy of Management Review", vol. 23, no. 3, 393-404.

Shaw R.B. (1997), Trust in Ballance, San Francisco: Jossey-Bass Publishers.

Shore L.M., Barksdale K., Shore T.H. (1995), Managerial Perceptions of Employee Commitment to the Organization, "Academy of Management Journal", vol. 38, no. 6, pp. 1593-1615.

Sztompka P. (1999), Trust: A Sociological Theory, Cambridge: Cambridge University Press.

Tabak F., Smith W.P. (2005), Privacy and Electronic Monitoring in the Workplace: A Model of Managerial Cognition and Relational Trust Development, "Employee Responsibilities and Rights Journal", vol. 17, no. 3, pp. 173-189.

Thomas C.W. (1998), Maintaining and Restoring Public Trust in Government Agencies and their Employees, "Administration \& Society", vol. 30, no. 2, pp. 166-193.

Tzafrir S.S. (2006), The relationship between trust, HRM practices and firm performance, "International Journal of Human Resource Management”, vol. 16, no. 9, pp. 1600-1622. 
Vanhala M., Ahteela R. (2011), The effect of HRM practices on impersonal organizational trust, “Management Research Review”, vol. 34, no. 8, pp. 869-888.

Wang X., Van Wart M. (2007), When Public Participation in Administration Leads to Trust: An Empirical Assessment of Managers' Perceptions, "Public Administration Review", vol. 67, no. 2, pp. 265-278.

Welter F. (2012), All you need is trust? A critical review of the trust and entrepreneurship literature, "International Small Business Journal", vol. 30, no. 3, pp. 193-212.

Whitener E.M., Brodt S.E. Korsgaard M.A., Werner J.M. (1998), Managers as initiators of trust: An exchange relationship framework for understanding managerial trustworthy behavior, "The Academy of Management Review", vol. 23, no. 3, pp. 513-530.

Wicks A.C., Berman S.L., Jones T.M. (1999), The structure of optimal trust: moral and strategic implications, "The Academy of Management Review", vol. 24, no. 1, pp. 99-116.

Zaheer A., McEvily B., Perrone V. (1998), Does trust matter? Exploring the effects of interorganizational and interpersonal trust on performance, "Organization Science", vol. 9, no. 2, pp. 141-159.

\section{Electronic bibliography}

Starnes B.J., Truhon S.A., McCarthy V. (2005), Organizational Trust: Employee-Employer Relationships [Online], Available: http://asq.org/hdl/2010/06/a-primer-on-organizationaltrust.pdf [2 Aug 2015]. 